\title{
A life-course perspective of South American women's experiences as care workers in Switzerland
}

\author{
Romina Seminario \\ Social Sciences Institute, Lausanne University, Géopolis - Office 5321, CH-1015, Switzerland
}

\section{Introduction}

The aim of this article is to understand how some immigrant women achieve skilled care jobs while others remain in less skilled and informal jobs in the care sector. Although I describe the segregation of these women into precarious segments of the labour market, such as domestic care work, my main interest lies in demonstrating that care jobs are heterogeneous in terms of skills and settings, and immigrant women's positions in the care sector are not fixed in time. In so doing, I focus here on how similar trajectories among South American care workers in Switzerland lead to different positions in the care sector. Paradoxically, women who accepted career paths in the care sector achieved better working conditions, while women who looked for other alternatives remained in precarious working conditions in the care sector. I propose three dimensions of their life stories to understand their current position: couple's negotiations, social network composition and professional aspirations.

The article is based on qualitative research about the combination of transnational family care work and paid care work among South American care workers in Switzerland. This project used biographical interviews and participant observation in a variety of settings (women's residences, family reunions and immigrant associations' events). Here, I focus only on a particular group of these immigrant women: urban, middle-class, young women with post-compulsory education degrees ${ }^{1}$ from their home countries who arrived and/or stayed with no legal authorization in Switzerland, worked in lesser skilled and informal care jobs, married a European Union (EU) or Swiss citizen, obtained legal authorization to work by family reunification, had children and temporarily withdrew from the labour market to care for their own children in Switzerland. The aim is to understand how some of them progressed onto more skilled jobs while others fell into a "precarious job trap" in the care sector. I am interested in how these migrant women have coped with gendered and racialized labour market segregation that might only offer a career in care.

This article is structured around five main sections. After briefly presenting the Swiss migration and care regime as well as the gender and nationality composition of the Swiss labour market, I will present a short review of the theoretical perspectives to analyse skilled and less skilled care workers, before presenting my research methods and analysing how South American women who share similar trajectories cope with labour market segregation. In the conclusion, I argue these women encountered paradoxical outcomes from their labour market participation: better employment conditions were achieved by women who accepted the care career path, while those who tried to exit this employment sector endured precarious employment conditions.

\section{South American women as care workers in Switzerland}

The Swiss migration and care regimes show gender and nationalitybased inequalities in terms of legal entry and opportunities for paid work. In this section, I summarize institutional and statistical information on these two themes.

\subsection{Migration and care regime}

Based on jus sanguinis and federalism, the Swiss migration regime is classified as one of the most restrictive, regarding the admission, residence and naturalization of foreigners (Huddleston, Niessen, Ni Chaoimh, \& White, 2011). The Agreement of Free Movement of Persons with the EU in 2002 and the new Federal Act on Foreign Nationals in 2008 have marked the Swiss migration regime's recent evolution. A hierarchy between EU and non-EU citizens has been established. For instance, non-EU foreigners' access to the Swiss labour market depends on proving that they possess higher and scarcer skills than Swiss citizens and EU foreigners.

The stratification of foreigners ${ }^{2}$ is part of a skills-based selectivity policy (Raghuram, 2008). The Federal Statistics Office (FSO) showed that $35 \%$ of migrants held a post-compulsory education degree, whereas $30 \%$ of the non-migrant population achieved the same level in 2014 (FSO, 2016). Indeed, a scarcity exists within the highly skilled

\footnotetext{
E-mail address: rominaangie.seminarioluna@unil.ch.

${ }^{1}$ Post-compulsory formation degrees refer to vocational and university formation after compulsory education.

2 "The term foreigner (living in Switzerland either temporarily or long term but not having Swiss citizenship), rather than immigrant (foreign-born) is used in Swiss legislation and statistics. This results from a citizenship law based on the principle of descent rather than on place of birth" (Riaño \& Baghdadi, 2007, p. 164). I use the term immigrant to emphasize the national origin and to analyse the changes in legal status.
} 
domestic workforce, which is solved by hiring foreign specialists (SECO, 2016). However, the rate of employees with post-compulsory formation working in a job that does not require such qualifications was higher among migrants (18.8\%) than among the non-migrant population (11.5\%) in 2014 (FSO, 2016). Furthermore, the professional profiles of the technology and finance sectors set the standards for "desired" foreign workers. However, immigrant women's professional profiles do not commonly match these standards for obtaining a work permit. Thus, non-EU women in Switzerland might gain access to Swiss labour markets through family reunification procedures. In analysing the requisites for family reunification, a traditional family model is evoked: the male breadwinner and female caregiver model (Riaño \& Baghdadi, 2007). Indeed, the renewal process of family permits depends on proving cohabitation, the performance of family responsibilities, etc. (Riaño, 2011; Riaño \& Baghdadi, 2007). In this sense, immigrant women are encouraged to fulfil a housewife role rather than participate in the labour market.

The Swiss care regime moulds the employment of immigrant care workers. The immigration of skilled and less skilled care workers, which comprise a highly feminized sector, has not been recognized as being significant and profitable. The scarcity and expensiveness of child and elderly care services hinder women's labour market participation, since family care is considered predominantly women's work (Baghdadi, 2010). For instance, Swiss women's engagement in the labour market is subordinated to their family situation, resulting in a preponderance of part-time jobs and discontinuous professional trajectories $^{3}$ (Giraud \& Lucas, 2009). Since most Swiss households cannot find or afford formal childcare services, hiring a migrant care worker under precarious conditions is a common practice (Baghdadi, 2010). Regarding skilled care workers, foreign degrees ${ }^{4}$ are subject to regulations from the state, higher education institutions and professional associations. Concerning less skilled care workers, there is an informal sector occupied by immigrants without authorization to work.

\subsection{Nationality and gender composition of the Swiss labour market}

Although South Americans in Switzerland represent a minority in comparison to EU citizens, they are a feminized (63\% women in 2013) and skilled group (41\% arrived with post-compulsory education between 2011 and 2015) (FSO, 2016; NCCR ON THE MOVE, 2017). There were 88,385 5 South Americans in 2013: 40\% came from Brazil, 13\% came from Colombia and $11 \%$ came from Peru (FSO, 2016). However, $43 \%$ of undocumented foreigners in Switzerland also came from Central and South America, and most of them work for private households (Morlok et al., 2015).

Drawing on Simonazzi, I define the care labour market as being composed of multiple types of workers, including "skilled workers such as licensed nurses; unlicensed low-skilled assistants and other workers providing personal care; domestic service workers providing home help with domestic shores" (Simonazzi, 2008, pp. 9-10). It has an important proximity with health, education and social services. Migrants' care work has been extensively debated thanks to Hochschild's seminal work on global care chains (GCCs) (Hochschild, 2001). The commodification of maternal care work between households and North-South

\footnotetext{
${ }^{3}$ Although $60 \%$ of women entered the labour market in $2015,58.7 \%$ of them worked part-time, whereas only $16.4 \%$ of men did the same (FSO, 2016). The presence of small children increases gender inequalities: Only $9.6 \%$ of couples with children showed two spouses working full-time, while $29.5 \%$ of couples showed men working full-time and women working part-time in 2015 (FSO, 2016).

${ }^{4}$ Highly skilled and skilled care jobs belong to the welfare sector. Regulation mechanisms for managing a foreign workforce are tougher than those in other employment sectors such as finance, management and engineering (Kofman, 2000; Kofman \& Raghuram, 2006).

5 This numbers do not consider South Americans without legal authorization.
}

geopolitical inequalities are key features. Yet, scholars advocate for also including settings such as public institutions and community-based organizations; highly skilled and skilled workers such as nurses, social workers and educators (Yeates, 2012; Kofman and Raghuram, 2015); and links to social reproduction tasks in which the interpersonal dimension is less central (Kofman and Raghuram, 2015).

In this article, social reproduction tasks such as cleaning and catering are related to the interpersonal dimensions that are central to care work. To different degrees, these dimensions are present in higher and lesser skilled care occupations. While acknowledging the differences in these tasks, immigrant women are frequently hired to clean, care and cater simultaneously and/or experience jobs with different combinations of these tasks throughout their careers. This article uses the concept of care work to analyse jobs that combine interpersonal, cleaning and catering dimensions as well as the dynamics of careers in a particular employment sector along gender and nationality lines.

The care sector is highly feminized and racialized ${ }^{6}$ in Switzerland. Based on the International Standard Classification of Occupations (ISCO 08) used by the FSO to create Tables 1 and 2, I propose to consider the distributions of national groups along skill levels. Moreover, the ISCO 08 classification includes care occupations at each level of skills. ${ }^{7}$ As indicated in Table 1, immigrants from "outside Europe", which includes South American citizens, are predominantly in the professionals $(26.2 \%)$ and service and sale workers $(25.3 \%)$ categories. In contrast with other national groups (e.g. Eastern Europeans), South American citizens might be found in occupations with higher and lower levels of skills: a sandwich distribution (Aratnam, 2012).

Besides segregation by nationality, the Swiss labour market also shows gender segregation. Table 2 shows immigrant and non-immigrant women comprising higher percentages of the service and sale workers category than their male counterparts. However, immigrant women show the highest rate: $25.1 \%$. In addition, immigrant women show higher rates in the technicians and associated professionals and elementary occupations categories than their male counterparts. Consequently, immigrant women are distributed throughout skill-based occupations within the care sector (e.g. as nurses at hospitals, homebased skilled caregivers, less skilled domestic helpers, etc.). However, jobs related to housework such as cleaning, washing and ironing show the highest concentrations of foreign women, whereas health and education jobs show the highest concentrations of Swiss women (Charles, 2005). Invisible to statistics, immigrant women are also found in the informal ${ }^{8}$ care sector (Morlok et al., 2015).

\section{III. Immigrant women's care jobs at different levels of skills}

Three corpora of literature have advocated for a gendered perspective on migration studies: the GCC, skilled migration and family

\footnotetext{
${ }^{6}$ As Francesca Scrinzi stated, there is a differentialist or culturalist racism that naturalizes cultural differences and xenophobia: migrants' situations are explained by their different "mentality", culture, religion, etc. and it is natural for human beings to have a culture and to be hostile towards foreigners. A genealogic conceptualization of nationality also exists. This means that integration of a migrant into another culture is doomed to fail (Scrinzi, 2013, pp. 50-51).

${ }^{7}$ At the professional segments, there are health professionals (doctors, nurses and midwives), teaching professionals and social work and counselling professionals. Within the technical segment are associated professionals and assistants in health and social work. At the service level are domestic housekeepers, childcare workers and teachers' aides, care assistants and home-based personal care workers. Among the elementary occupations are domestic cleaners and helpers.

${ }^{8}$ Informal employment or undeclared work is defined as all remunerated activities that are in principle legal but hidden from the state, in that they are not declared to the public authorities, though the regulatory system of the specific state requires their declaration (Pfau-Effinger, Flaquer, \& Jensen, 2009, p. 5).
} 
Table 1

Distribution according to ISCO-08 occupations, nationality and geographical division in 2014 GCC.

Source: own elaboration based on (FSO, 2016).

\begin{tabular}{llll}
\hline $\begin{array}{l}\text { Nationality, geographical division } \\
\%\end{array}$ & Switzerland & $\begin{array}{l}\text { Eastern } \\
\text { Europe }\end{array}$ & $\begin{array}{l}\text { Outside } \\
\text { Europe }\end{array}$ \\
\hline Managers & 8.2 & 4.7 & 7.5 \\
Professionals & 25.7 & 12.6 & 26.2 \\
$\begin{array}{l}\text { Technicians and associated } \\
\quad \text { professionals }\end{array}$ & 20.1 & 9.1 & 11.2 \\
$\begin{array}{l}\text { Clerical support workers } \\
\text { Service and sale workers }\end{array}$ & 10.1 & 5.3 & 5.6 \\
Skilled agricultural, forestry and & 15.1 & 21.2 & 25.3 \\
$\quad 3.8$ & $(1.1)$ & $(0.5)$ \\
$\quad$ fishery workers & & & \\
Plant and machine operators, and & 11.0 & 22.5 & 8.4 \\
$\quad$ assemblers & 3.0 & 8.3 & 4.1 \\
Elementary occupations & 2.5 & 14.8 & 10.7 \\
Not attributed & 0.4 & $(0.5)$ & $(0.4)$ \\
Total & 100 & 100 & 100 \\
\hline
\end{tabular}

Table 2

Distribution according to ISCO-08 professions, gender and migration in 2014 . Source: own elaboration based on (FSO, 2016).

\begin{tabular}{|c|c|c|c|c|}
\hline \multirow[t]{2}{*}{ Gender, migration status \% } & \multicolumn{2}{|c|}{$\begin{array}{l}\text { Non-immigrant } \\
\text { population }\end{array}$} & \multicolumn{2}{|c|}{ Immigrant population } \\
\hline & Women & Men & Women & Men \\
\hline Managers & 5.8 & 10.2 & 7.0 & 10.5 \\
\hline Professionals & 25.1 & 26.2 & 22.8 & 24.2 \\
\hline $\begin{array}{l}\text { Technicians and associated } \\
\text { professionals }\end{array}$ & 22.7 & 18.3 & 17.2 & 14.4 \\
\hline Clerical support workers & 15.2 & 5.3 & 10.0 & 4.9 \\
\hline Service and sale workers & 20.8 & 9.2 & 25.1 & 12.5 \\
\hline $\begin{array}{l}\text { Skilled agricultural, forestry } \\
\text { and fishery workers }\end{array}$ & 2.5 & 6.0 & $(0.0)$ & 1.2 \\
\hline $\begin{array}{l}\text { Craft and related trades } \\
\text { workers }\end{array}$ & 3.8 & 17.9 & 4.4 & 21.0 \\
\hline $\begin{array}{l}\text { Plant and machine operators, } \\
\text { and assemblers }\end{array}$ & 1.0 & 4.6 & 2.0 & 7.2 \\
\hline Elementary occupations & 2.8 & 1.7 & 10.6 & 3.5 \\
\hline Not attributed & $(0.3)$ & 0.5 & $(0.4)$ & $(0.5)$ \\
\hline Total & 100 & 100 & 100 & 100 \\
\hline
\end{tabular}

migration literatures. However, dialogue among them has been limited. The GCC literature has focused on particularly disadvantaged groups of immigrant women that performed home-based care work in Global North countries leaving their children behind, while rendering other profiles invisible, such as highly skilled and skilled immigrant care workers, and single and childless immigrant women. Likewise, the entrance of skilled women into Northern countries does not correspond to one path, such as irregular legal situations, but also to other legal categories that change over time. Family reunification is an important legal outlet that evokes transnational family relations, such as bi-national marriages with children in the host country.

GCC studies emphasize the power relations between immigrant women as employees and native women as employers as well as the market's segregation of immigrants based on gender and race discrimination (Hochschild, 2001; Hondagneu-Sotelo, 2001; Salazar Parreñas, 2001). Indeed, this approach provided a breakthrough for understanding how migrant women face the expansion of inequalities across the globe. However, there are some gaps. These analyses consider immigrant and native women as homogeneous groups, with the former as underprivileged mothers and the latter as wealthy professionals (Morokvasic, 2011). The analysis also seems to consider circumstances in Northern countries without analysing the different socioeconomic backgrounds of immigrant women. In short, the focus on informal, less skilled and home-based care jobs performed by immigrant women who have childcare responsibilities in their home countries renders invisible other types of jobs in the care sector as well as different professional and family situations (Yeates, 2012).

Feminist scholars have pointed out the scant attention given to skilled immigrant women in general and those in the care sector in particular (Dumitru, 2014; Kofman \& Raghuram, 2006; Wong, 2014). In fact, the global economy is not a polarised schema of highly skilled and masculine immigration streams such as transnational corporate movements versus feminized immigration streams of informal and precarious domestic care workers (Kofman, 2000). Skilled immigrant women have been circulating but in different ways. Women's immigration is not circumscribed to less skilled segments of the care sector, and the category of skilled migrants is heterogeneous. For instance, care workers are employed in private and public institutional settings. Besides being employed in childcare and cleaning, they are also doctors, nurses and teachers.

Considering immigrant women also addresses an intersection of family and legal situations: family reunification. Current migration literature has emphasized the transnational circulation of care among family members (Baldassar \& Merla, 2014). Besides transnational mothering, immigrant women participate as daughters, siblings and spouses. They not only leave their family behind but also create new family relations through bi-national marriages. In this sense, they might also change their legal situations. Legal categories evolve over time, and actors use these categories differently (Schrover \& Moloney, 2013). Moreover, family reunification conditions particularly express controls for settlement, economic and political rights (Kraler, Kofman, Kohli, \& Schmoll, 2011). In fact, family reunification might be an important source of skilled female immigration. Consequently, immigrant women have multiple transnational family circumstances and face legal conditions differently. However, the literature has not focused on skilled female members of transnational families or on the gendered impact of family reunification on high and less skilled immigrant women.

I propose a life-course perspective to grasp immigrant women's multiple and evolving experiences in the care sector. Two analytical principles of this approach are useful to understand the life stories of migrant care workers: the "linked lives" principle, which grasps the role of social relations, and the "temporality" of events, to analyse the relations between and quality of events at different live domains (e.g. family, work) in lifelong processes (Alwin, 2012; Sapin, Spini, \& Widmer, 2014). Here, the analysis involves comparing skilled and unskilled employment outcomes as well as the movements between the upper and lower segments of the care sector. Given that trajectories are not unidirectional, migrant women experience upwardly/downwardly mobile careers and changes in legal status and family dynamics. Adopting this dynamic and time-sensitive approach enables us to escape the pitfalls of homogenizing this group of foreign female workers and this employment sector.

\section{Research methods}

The research findings are based on interview data and field notes collected during 2009-2010, in various settings: immigrant women's residences and events organized by immigrant associations in a large French-speaking city in Switzerland. I conducted seventeen biographical interviews with South American women employed in the care sector (most of them were from Peru but also from Argentina, Colombia and Ecuador) (Seminario, 2011). My interview guide contained questions about the content of their transnational family care work and the paid care work at the destination as well as their perceptions about the differences and similarities between them.

Most of these women came from urban working and middle classes in their home countries, were enrolled in post-compulsory formation centres (e.g. technological institutes and universities) and had rarely performed paid care jobs until migration (see Table 3). Six of them stopped their education at the compulsory level, and only one of them 
was a paid domestic employee back home. They represent a heterogeneous group based on employment, family and legal conditions at the destination. The group ranges from live-in nannies and housekeepers to hourly paid baby sitters and cleaners, health and nursery aids and professional nurses. They work in their employers or beneficiaries' houses and at public or private institutions, with and without legal authorization. Although half of them (8) worked as hourly paid cleaning ladies, and most of them had worked as nannies or still worked babysitting hours. Considering their lack of authorization to work, cleaning jobs in private households frequently involved an interpersonal dimension: building trust with the employers to guarantee stable jobs, avoid denouncement to the police and obtain references for other jobs. Most of the cleaning ladies worked for several years for the same employers and worked for members of the same family (e.g. the daughters). Cleaning ladies invested in the interpersonal dimension by accepting babysitting hours, cooking dinner for the employers' family, etc. And, those who were skilled care workers (4) had also performed cleaning jobs at arrival, and their current caring tasks with patients involved cleaning at institutions or private houses, in different degrees. Considering the place of interpersonal dimensions in these cleaning jobs and the systematic experience of child and elderly care in their careers at the destination, these immigrant women portray the evolving job configurations in the care sector by showing less to more skilled jobs as well as less to more interpersonal-based jobs. Although the divisions between cleaning and interpersonal tasks are important, the focus on this article is on the dynamics of care jobs and the trajectories in the employment sector.

Contact with participants was established through personal networks and immigrants' associations. Members of associations introduced me to the first participants, who gave me the names of other possible contacts who did not participate in associations ("snowball method"). Thanks to one member, I also became friends with a group of four cleaning ladies and nannies who lived together in an apartment that was close to my student dorm, and I spent many afternoons talking with them about their daily routines and helping them with their computers and Internet connections to communicate with their families back home.

My own immigration experience of being a Peruvian woman in her late twenties living and studying in Switzerland helped me to carry out the interviews in Spanish, meet other Spanish-speaking South Americans and understand their experiences. However, my social class, gender and racialized position (as a holder of an HE degree and scholarship as well as a legal resident in the host country with a "whitish" appearance) affected the kind of contacts established, the interviews' situation and the analysis. While the women with adult children back home showed a "motherly" attitude (e.g. sharing their meals with me), those who were younger and more skilled showed suspicion about my questions and/or interest in how I obtained a scholarship and became enrolled at a Swiss university.

For the analysis, I present ideal-types, defined by Weber as "formed by the one-sided accentuation of one or more points of view and by the synthesis of a great many diffuse, discrete, more or less present and occasionally absent concrete individual phenomena, which are arranged according to those one-sidedly emphasized viewpoints into a unified analytical construct. In its conceptual purity, this mental construct cannot be found empirically anywhere in reality" (Weber, 1904/ 1949, p. 90). There is a stylisation process in constructing ideal-types that involves accentuating the key features of the phenomenon under study (Schnapper, 1999). The preliminary analysis, which involved comparing each care worker's biographies, suggested patterns of differences based on family and professional background and current position in the labour market. The ideal-types include two dimensions based on findings in the empirical material: the positive or negative relations between family and professional trajectories as well as the employment outcomes at the destination.

Three ideal-types were created: the first ideal-type portrays the 
positive relations between the family and professional trajectories made of parents' support, the absence of family responsibilities and access to post-compulsory education in the home country as well as the conciliation between partnership and parenthood in Switzerland, in combination with upward mobility in the care sector. The second ideal-type differs from the first one predominantly in the downgrading of professional experience at the destination, such as the continuous performance of precarious care jobs by migrant women with post-compulsory training in other occupations. The third ideal-type evokes the situation of migrant women who suffer negative relations between their family and professional trajectories and show the continuity of precarious jobs from the homeland to the host country. This type is the only one that reassembles the common image in the GCCs of migrant women as poorly skilled workers and lone parents.

In comparing these ideal-types to individual cases, the first one represented three interviewees (cases 1 to 3 in Table 3). The second one represented eight interviewees (cases 4 to 11 in Table 3), and the third one represented six interviewees (cases 12 to 17 in Table 3). The idealtypes do not exactly portray the individual experiences of the research participants but propose key dimensions with which to understand the mobility of migrant care workers in the labour market, such as the relations between family and professional trajectories in both countries and the paths into employment outcomes at the destination.

Although I identified three ideal-types, I develop the analysis of two types in this article. While these two types included fewer interviewees than the other type, they represent under-researched cases in the literature: migrant care workers with high-skill training and employment history and the capacity to delegate family responsibilities who showed upward or downgrading mobility.

\section{Analysing two life stories of South American care workers in Switzerland}

My main interest is to understand how some immigrant women progress onto more skilled jobs while others fall into a "precarious job trap" in the care sector. I am interested in how they cope with labour market segregation. The paths into both employment outcomes show the interactions among three dimensions: couple's negotiations, social network composition and professional aspirations that explain the social mechanisms that differentiate the first ideal type from the second one. To understand these social mechanisms, I illustrate the two idealtypes with individual life stories: Nuria and Clayde. This two life stories have the potential to exemplify the social mechanisms triggered by a similar event: an encounter with an employment counsellor. Although the other interviewees in the two ideal-types did not experience the same event, the comparison of two life stories that shared a similar event enables me to explain the social mechanisms in an orderly manner and clearly signal the differences in the interactions of the three dimensions. Nevertheless, my analysis does not assume that these events are the sole explanation for the bifurcation into upwardly mobile or downgrading professional experiences at the destination.

Consequently, the encounter with employment counsellors represented a turning point in the two life stories that triggered the interaction of couple's negotiation, social networks and professional aspirations. To illustrate the two life stories, I thus focus on how achieving an ascending career path depends on having a highly skilled and successful partner, fewer and distant relations with other migrant care workers and aspirations for qualified jobs in general. In contrast, the experience of a descending professional trajectory depends on the spouse's less privileged position in the labour market, more and closer relations with other migrant care workers and the strong desire to exit the care sector.

In the following sections, I present the life stories of Nuria and Clayde, who had similar family and professional backgrounds but different employment outcomes in the care sector. Both women belonged to urban middle-class families and earned post-compulsory degrees in their home countries. Their parents paid for their training in technological institutes, and their migrations were possible thanks to family members abroad. Since both young women arrived by irregular means, legal authorization to settle and work in Switzerland was not possible for them. Except for one, all the interviewees in both ideal types were enrolled in post-compulsory training, although only seven obtained degrees (see Table 3). Thanks to their social networks, Nuria and Clayde found jobs and worked for some years in the informal care sector, like all of the other interviewees. In the cases of Nuria and Clyde, their legal status was regularized through marriage to an EU or Swiss citizen. Although all the interviewees in the first type earned authorization to work by means of bi-national marriages, only three of them did so in the second type. Clayde and Nuria gave birth and retreated from the labour market. Interviewees in both ideal-types showed heterogeneous family situations, with a minority of women not having children and a majority having children in Switzerland or the home countries; however, the couple's negotiations about caregiving, as I will show, play an important role in all situations. When Clayde's and Nuria's children grew older, Clayde and Nuria decided to explore their chances for paid work again. Since both of them were authorized to work, they looked for advice at an employment agency. ${ }^{9}$ Both received the same "advice": job hunting in the care sector. Afterwards, their employment outcomes were oppositional: despite having similar backgrounds, one of them achieved a skilled care job, while the other remained in unskilled care jobs. Although Nuria and Clayde were the only ones who had encounters with employment counsellors, the social mechanisms triggered during and after this event are found in the experiences of other interviewees: couple's negotiations, social network composition and professional aspirations. Paradoxically, the women who embarked on a career path in the care sector enjoyed better employment conditions currently than the women who tried to work in other sectors based on their prior qualifications but remained in the informal, less skilled and precarious segment of the care sector.

\subsection{Accepting the challenge of a career in the formal care sector: re-training}

Nuria is a Peruvian advertising professional that got married in Switzerland to an EU engineer and has one small daughter. She has one younger brother living in Peru with her mother. She was raised in a lower middle-class neighbourhood in the biggest city of the country. After compulsory education, she earned a degree in a technological institute but she struggled to find work commensurate to her skills. In 2002, she came to Switzerland by passing with no visa through Germany looking for a job and was helped by an aunt who was already living there. At 19 years old, she started working as a cleaning lady and a nanny until she met her future husband. At age 22, she got married and had a daughter. After two years, she went to ask for counselling at the unemployment office. The counsellor advised her to change her track and undertake training in the care sector. She had to repeat three years of high school to enroll in early childhood education at the university. In addition, she needed to clock up some previous professional experience accordingly. She thus did a six-month traineeship in the crèche of a multinational company. At that time, her daughter was attending a public kindergarten from 7.30 am till $6 \mathrm{pm}$ : she was dropped off and picked up by her father. Thanks to the recommendation letter of her employers, she was admitted at the university and changed her job contract with the private nursery to start an apprenticeship. ${ }^{10}$ So, she worked for three days a week at the private nursery and had courses two days a week. Since her daughter started school, she has to adapt the care arrangements to a schedule with a lunch-break at home. Given that her husband also works full time as an engineer, they

\footnotetext{
${ }^{9}$ In Switzerland, interviews with an employment counsellor are also a requisite to obtain unemployment benefits.

${ }^{10}$ The apprenticeship includes practical and theoretical modules.
} 
hired an au-pair of Ecuadorian origin and Spanish residence permit to be in charge of the daily care of her daughter.

Nuria's story shows a particular way to cope with the devaluation of home countries' education credentials and the advice to look for a job in the care sector. Having a highly skilled husband with a well-paid job, she also aspired to achieve a skilled job. Thus, she fulfilled all the requisites to embark in an upwardly mobile career in the care sector. Being the mother of a small daughter, she also had to manage family care work to succeed a time-consuming retraining program that combines formation and employment. In this sense, she confronted the limitations of the Swiss welfare regime where sufficient economic resources and support from other family members are essential. Husband's salary and working timetable, as well as, his willingness to help out allow her to combine paid care services and home caregiving. For instance, the re-adaptation of family-work arrangements due to school's schedules did not put at risk her career. Indeed, hiring a live-in nanny (au pair) was possible thanks to the couple's sufficient economic resources and the availability of affordable care services, often provided by other immigrant women. She preferred to become an employer of another South American women than asked another family member for help.

Although obtaining a skilled job in the formal care sector meant a long path to go, it represented many advantages: good salary, employment stability, social benefits and continuous training. Since there is scarcity of skilled care workers with legal authorization to work, she could find a full-time position in a private nursery quickly. Currently, she is part of a double-career bi-national couple. However, Nuria continues to struggle with employment-family arrangements such as performing family hands-on care and supervising the work of the hired aupair.

\subsection{Working intermittently in the care sector: aspiring to exit}

Clayde is an Ecuadorian professional secretary married to a Swiss pilot of Argentinian origin and has two small children. She came from an urban middle-class family with divorced parents and three children. After obtaining her post-compulsory formation degree, she started to work as an accounting assistant in a school. She had already tried to obtain a visa to USA unsuccessfully, when she was invited to Switzerland in order to help an in-law with caregiving. She came to Switzerland in 2000, at the age of 25, passing through the French border with no visa. She started working as a maid and nanny, especially with Spanish-speaking families. After two years in Switzerland, she helped her younger sister to follow in her steps. Then she got married with a Swiss citizen of Argentinian origin and had her first child in 2005. Afterwards, she went to the unemployment office. Although she explained her professional background and preferences for working as a cashier or salesperson, the counsellor told her to accept cleaning jobs and mailed her only information of cleaning enterprises. Also, she asked for French courses to improve her language skills, but the counsellor refused, arguing that caring/cleaning jobs didn't require those skills. Eager to achieve her professional aspirations, Clayde refused this advice and started job-hunting on her own. Thanks to her husband's job as a public employee, they had a place in a nursery, and they informally hired other South American women for babysitting and cleaning hours. Then, she tried again the unemployment office. She wanted to find jobs outside the care sector and/or start a course to become a salesperson or cashier. Since she did not follow the previous counsellor's advice, she could not get an appointment. In the meantime, she gave birth to her second child who had health problems. Currently, the children go to the nursery almost all weekdays and her older son goes to school. She coordinates with her husband the daily caregiving and continues to employ other immigrant women. At age 34 , she manages to work $2 \mathrm{~h}$ at night during the week as a concierge for a sports club and one day a week as a maid for a former employer of her sister.

Clayde's story shows another way of coping with the devaluation of home countries' education credentials and the advice to look for jobs in the care sector. Having a professional ambition for jobs according to her earlier qualifications outside the care sector, she refused the advice of the counsellor and tried to exit this sector on her own. In contrast with Nuria, Clayde's husband who was born in Argentina also suffered from deskilling in Switzerland. Being a pilot with Argentinian credentials, he was asked to repeat courses and exams in order to fly. Due to scarcity of financial resources, he desisted and accepted less skilled jobs. This negative antecedent of unemployment counselling increased Clayde's suspiciousness of the advice given to her. Nevertheless, the employment status of Clayde's husband provided childcare. Besides her own caregiving, her husband's contributions and nursery services, she paid informally baby-sitting and cleaning hours. In fact, she uses her social network to hire recently arrived South American women until they find stable and better-paid jobs. However, the frontier between mutual aid and exploitation is blurry among employee-employer and friendship relations. In contrast to Nuria, other South American care workers are an important component of Clayde's social network. Among these women, care jobs are not highly valued because of the precarious working conditions they experienced.

Although she handles family caregiving to exit the care sector, she continues to work as an hourly paid concierge and cleaning lady without contract or social benefits. Her husband's modest salary in combination with her scant interest for a care re-training program ruled out the long reskilling path of Nuria. Paradoxically, the choice of trying to get work based on her earlier qualifications out of the care sector contributed to her being still employed under precarious working conditions in this sector. Moreover, her labour market participation diminished compared to the moment of arrival in the host country. Indeed, Clayde's current labour participation does not match the desired occupation rate in the formal sector neither her professional aspirations outside the care sector. Segregated to precarious jobs and performing tasks without satisfaction, Clayde's story shows how the struggles to earn the recognition of earlier qualifications outside the care sector may reinforce the retreat from the formal segments of the labour market at the destination. In this way immigrant women's noncare professional aspirations are not encouraged.

The two life stories of South American care workers demonstrate obstacles to access the Swiss labour market according to professional aspirations, experiences and credentials. Yet, these stories represent evolving unequal social positions within this group: two ideal-types. For the first one, Nuria's story exemplifies the compliance and completion of the professional project pointed to South American women. She used her favourable conditions such as husband's economic and caregiving support to achieve the professional goals of a skilled job in Switzerland. The other life stories of upward mobility in the care sector show the role of the husband to delegate family responsibilities and support skilled jobs, for example Paola married a male nurse that influence her professional reconversion by the means of nursing studies.

For the second ideal-type, Clayde's story shows how the refusal of the appointed care career path makes it clear the barriers to earn the recognition of earlier qualifications outside the care sector and performed formal skilled jobs. In this case, her husband's professional trajectory also informed this decision. Contrary to Nuria, Clayde's network composition contains other South American women who perform informal, unskilled and badly paid care jobs predominantly, which might reinforce negative opinions about this sector. The other life story in the downgrading ideal type also shows the role of networks with other migrant care workers in the perception of these jobs. For instance, Maria as a newly arrived entertained relations with unauthorized migrant women that helped her to find her first jobs as an informal hourly paid babysitter and cleaning lady. Provided that she had the legal authorization to work, these friends discouraged her to accept care jobs. She decided to start looking for jobs outside the care sector. Despite the fact of having a university degree, she only had job offers as a waitress that involve longer hours and lesser hourly wage than her care jobs. 
The two ideal-types show the heterogeneity and stratification of employment conditions in the care sector that enables some of these women to fulfil their professional aspirations of skilled jobs and blocks other women into precarious care jobs against their eagerness to exit them. The paradoxical results of the employment outcomes as care workers of these two ideal-types depend on: couple's negotiation (husband's professional trajectory, employment conditions, caregiving and economic support) relations to other immigrant care workers (friendship and employment relations) and professional aspirations (skilled job or non-care job).

\section{Understanding paradoxical results of labour market participation among South American women as care workers in Switzerland}

The aim of this article was to understand how some immigrant women achieve skilled care jobs while others remain in less skilled and informal jobs in the care sector. Based on a typological thinking, I enquired the multi-directional trajectories of South American care workers in Switzerland: women who shared similar relations between family and professional trajectories (urban middle-class origin, postcompulsory education degrees, acquisition of legal authorization to work by the means of family reunification) but show different employment outcomes in the care sector.

The segregation of South American women in the Swiss labour market was specifically expressed in the two life stories by encounter with employment counsellors that 'suggests' them jobs in the care sector. In relation to employment, the ethnic penalty against immigrant population has been widely corroborated (Zschirnt \& Ruedin, 2016). Besides employers (Auer, Bonoli, \& Fossati, 2015), other actors such as counsellors evoke stereotypes about national groups that show a high impact on migrants' careers. At intersections with gender, these stereotypes about immigrants' qualifications are different for South American women, for instance the attribution of a docile and caring femininity. In combination with barriers for the recognition of foreign credentials, South American women are frequently identified with the least skilled care jobs in Switzerland. These mechanisms might also provide the necessary cheap and flexible workforce to the under-supplied Swiss care regime.

In addition, I identified three factors that explain how these migrant women particularly cope with gender and nationality-based segregation in the Swiss labour market: couple's negotiations, social network composition and professional aspirations. The two life stories show that achieving an upward career and skilled job involve embracing the care sector "suggestion" and fulfilling excessive reskilling requisites, whereas remaining in the lower segment of the care sector seem to start by refusing this suggestion and looking for alternative occupations autonomously. Assuming that immigrant women who accepts and pursues a career in the care sector will be confined to precarious working conditions and menial work does not correspond to Nuria's experiences. In contrast, immigrant women like Clayde who refuse to work in the care sector do not subsequently achieve a career outside it.

Couple's characteristics and negotiations influence South-American women labour market participation: the spouse's wage and employment conditions, as well as contributions to hands-on caregiving. Considering the Swiss care regime of traditional family model and scarcity of public services, couples with better economic resources can afford more convenient paid care services that alleviate some women's family caregiving and improve their labour market participation. In the case of migrant women, couple's negotiations might enable to accomplish requisites of professional reconversion into a care career. Consequently, undertaking a long re-training program to obtain a skilled care job might be easier for immigrant women who married also high-skilled and well-paid partners. Indeed, this situation might encourage immigrant women to also achieve a high-skilled job. Whereas having a partner who also suffered deskilling might discourage them to embark in a reskilling project.

Social networks' composition also influences employment outcomes. The professional trajectories of partners and close friends might promote or dissuade immigrant women to accept or not the care "suggestion". Being in touch with other South American care workers in the informal sector might prevent to pursue a care career. South American women also use their co-ethnic contacts to find affordable and flexible services. Indeed, they might engage in formal and informal employment arrangements with other South American care workers: e.g. fille-au-pair programs, informally paid services and favours. Employer-employee and friendships relations are combined under tension, confusion and inequality. Employing other South American women for informal care jobs might add to preferring other types of jobs for oneself after obtaining legal authorization to work in the host country. Hiring other South American women for formal care jobs instead of informal family help might add to appreciate formal and skilled jobs.

Employment outcomes in the care sector also depend on professional aspirations such as obtaining a skilled job in any sector or exiting the care sector. Considering this subjective dimension helps to understand these women's different reactions to obstacles in the Swiss labour market. As Dominique Epiphane, Irène Jonas and Virginie Mora stated "taking into account the subjective dimension of discrimination enables (the researcher) to render visible how discriminated women deal with themselves and the others to claim (again) ownership of their trajectories" (Epiphane, Jonas, \& Mora, 2011, p. 104). Instead of assuming "altruistic motivations" and "intrinsic rewards" related to care work (Hebson, Rubery, \& Grimshaw, 2015), I consider the multiple professional aspirations of these women. Professional experiences of significant others influence their professional goals. A highly skilled partner, lack of friendship relations but formal employee-employer relations with other immigrant care workers might foster the eagerness to obtain a skilled job regardless of the sector. Whereas a husband that suffered deskilling and friendship relations with other immigrant care workers that perform informal and precarious care jobs might convince these women to exit this sector and to recognize the 'care suggestion' as discrimination.

Care employment sector is not intrinsically devaluating. There are multiple and dynamic mechanisms that might explain upward and downward careers in the host country. These findings complement the conclusions of GCC about professional experiences of South American women care workers. While building on a local case study, the typology proposed is arguably relevant in two ways. Firstly, I demonstrated the heterogeneity inside the care sector and within immigrant women by comparing skilled and unskilled employment outcomes. In addition, I compare the legal situations and family circumstances of migrant women that create an internal hierarchy and power relations among them. Secondly, I show multi-directional professional trajectories of South American care workers in host countries thanks to a time-sensitive approach. This type of analysis sheds light on the interdependence of family and professional trajectories, the significance of events and actor's subjective choices.

\section{References}

Alwin, D. F. (2012). Integrating varieties of life course concepts. 67, 206-220. https://doi. org/10.1093/geronb/gbr146.Advance.

Aratnam, G. J. (2012). Les personnes hautement qualifiées issues de la migration. (Bern).

Auer, D., Bonoli, G., \& Fossati, F. (2015). It's discrimination, stupid: Labour market (re-) entry difficulties among different immigrant groups in Switzerland (working paper no. 2). (Neuchâtel).

Baghdadi, N. (2010). Care-work arrangements of parents in the context of family policies and extra-familial childcare provision in Switzerland (research reports no. 3\&4). (Geneva).

Baldassar, L., \& Merla, L. (2014). Transnational families, migration and the circulation of care. Understanding mobility and absence in family life. New York: Routledge.

Charles, M. (2005). Evolution de la ségrégation professionnelle en Suisse en fonction du sexe et de la nationalité de 1970 à 2000. Neuchâtel.

Dumitru, S. (2014). From "brain drain" to "care drain": Women's labor migration and methodological sexism. Women's Studies International Forum, 47(PB), 203-212. https://doi.org/10.1016/j.wsif.2014.06.006. 
Epiphane, D., Jonas, I., \& Mora, V. (2011). Dire ou ne pas dire... les discriminations. Agora Débats/Jeunesses, 57, 91. https://doi.org/10.3917/agora.057.0091.

FSO (2016). Integration indicateurs (Retrieved November 30, 2016, from) https://www. bfs.admin.ch/bfs/fr/home/statistiques/population/migration-integration/ indicateurs-integration.html.

Giraud, O., \& Lucas, B. (2009). Le renouveau des régimes de genre en Allemagne et en Suisse: bonjour 'néo maternalisme'. Cahiers Du Genre, 46(1), 17-46. https://doi.org/ 10.3917/cdge.046.0017.

Hebson, G., Rubery, J., \& Grimshaw, D. (2015). Rethinking job satisfaction in care work: Looking beyond the care debates. Work, Employment and Society(2013), https://doi. org/10.1177/0950017014556412.

Hochschild, A. (2001). Global care chains and emotional surplus value. In Vintage (Ed.). On the edge. Living with global capitalism (pp. 130-146). (London).

Hondagneu-Sotelo, P. (2001). Domestica. Immigrant workers cleaning and caring in the shadows of affluence. California. University of California Press.

Huddleston, T., Niessen, J., Ni Chaoimh, E., \& White, E. (2011). Migrant integration policy INDEX III. Suisse. Migrant integration policy INDEX III. Bruxelles.

Kofman, E. (2000). Female migrants and gender relations in studies of skilled migration in Europe. 59.

Kofman, E., \& Raghuram, P. (2006). Gender and global labour migrations: Incorporating skilled workers. Antipode, 38(2), 282-303. https://doi.org/10.1111/j.1467-8330. 2006.00580.x.

Kofman, E., \& Raghuram, P. (2015). Gendered Migrations and global social reproduction. London: Palgrave Macmillan.

Kraler, A., Kofman, E., Kohli, M., \& Schmoll, C. (2011). Issues and debates on familyrelated migration and the migrant family: A European perspective. Gender, generations and the family in international migration (pp. 11-54). Amsterdam: Amsterdam University Press.

Morlok, M., Oswald, A., Meier, H., Efionayi-mäder, D., Ruedin, D., \& Bader, D. (2015). Les sans-papiers en Suisse en 2015. (Bâle).

Morokvasic, M. (2011). L'(in)visibilité continue. Cahiers Du Genre, 51(2), 25. https://doi. org/10.3917/cdge.051.0025.

NCCR ON THE MOVE (2017). Proportion of migrants with tertiary education (Retrieved September 15, 2017, from) http://nccr-onthemove.ch/knowledge-transfer/ migration-mobility-indicators/how-qualified-are-migrants-in-switzerland/.

Pfau-Effinger, B., Flaquer, L., \& Jensen, P. H. (2009). Formal and informal work. The hidden work regime in Europe. Routledge.

Raghuram, P. (2008). Governing the mobility of skills. Governing international labour migration: Current issues, challenges and dilemmas (pp. 81-94). London: Routledge.
Riaño, Y. (2011). "He's the Swiss citizen, I'm the foreign spouse": binational marriages and the impact of family-related migration policies on gender relations. Gender, generations and the family in international migration (pp. 265-282). Amsterdam: Amsterdam University Press.

Riaño, Y., \& Baghdadi, N. (2007). Understanding the labour market participation of skilled immigrant women in Switzerland: The interplay of class, ethnicity, and gender. Journal of International Migration and Integration, 8(2), 163-183. https://doi. org/10.1007/s12134-007-0012-1.

Salazar Parreñas, R. (2001). Servants of globalization. Women, migration and domestic work. California: Stanford University Press.

Sapin, M., Spini, D., \& Widmer, E. (2014). Les parcours de vie. De l'adolescente au grand âge. Lausanne: Presses polytechniques et universitaires romandes.

Schnapper, D. (1999). La compréhension sociologique. Démarche de l'analyse typologique. Parus. PUF.

Schrover, M., \& Moloney, D. M. (2013). Making a difference. Gender, migration and categorisations: Making distinctions between in Western Countries, 1945-2010 (pp. 7-54). Amsterdam: Amsterdam: University Press.

Scrinzi, F. (2013). Genre, migrations et emplois domestiques en France et en Italie. Construction de la non-qualification et de l'altérité ethnique. Paris: Editions Petra.

SECO (2016). Pénurie de main-d'œeuvre qualifiée en Suisse. Système d'indicateurs pour évaluer la demande en personnel qualifié. (Bern).

Seminario, R. (2011). L'articulation de cadre familial et salarial du care: son organisation quotidienne et les parcours des migrantes sud-américaines à Lausanne en Suisse. Université de Lausanne.

Simonazzi, A. (2008). Care regimes and national employment models. Cambridge Journal of Economics, 1-22. https://doi.org/10.1093/cje/ben043.

Weber, M. (1904/1949). In E. A. Shils, \& H. A. Finch (Eds.). The methodology of the social sciences(1st ed.). Illinois: The Free Press of Glencoe. https://doi.org/10.1016/B978-008-019870-5.50010-2.

Wong, M. (2014). Geographies and strategies of caregiving among skilled Ghanaian migrant women. Women's Studies International Forum, 42, 28-43. https://doi.org/10. 1016/j.wsif.2013.11.005.

Yeates, N. (2012). Global care chains: A state-of-the-art review and future directions in care transnationalization research. Global Networks, 12(2), 135-154. https://doi.org/ 10.1111/j.1471-0374.2012.00344.x.

Zschirnt, E., \& Ruedin, D. (2016). Ethnic discrimination in hiring decisions: A metaanalysis of correspondence tests 1990-2015. Journal of Ethnic and Migration Studies, 42(7), 1115-1134. https://doi.org/10.1080/1369183X.2015.1133279. 